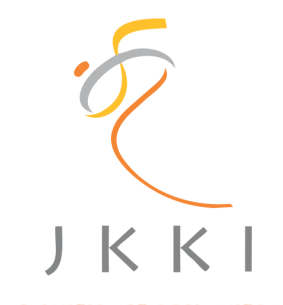

Jurnal Kedokteran dan Kesehatan Indonesia

Indonesian Journal of Medicine and Health

Journal homepage: https://journal.uii.ac.id/JKKI

\title{
Fahr's syndrome in teenage girls with systemic lupus erythematosus: A case report
}

Damar Prasetya ${ }^{1,}$ Sumadiono ${ }^{1}$

${ }^{1}$ Department of Child Health, Faculty of Medicine, Public Health and Nursing, Universitas Gadjah Mada/Sardjito General Hospital, Yogyakarta, Indonesia

Case Report

\begin{tabular}{|c|c|}
\hline \multirow[b]{2}{*}{ ARTICLE INFO } & \\
\hline & \multirow{6}{*}{$\begin{array}{l}\text { Fahr's disease or Fahr's syndrome is a condition characterized by } \\
\text { intracranial calcifications especially in basal ganglia and dentate nuclei. } \\
\text { They are a rare condition with a broad range of manifestations from } \\
\text { asymptomatic condition to severe neurological and psychiatry signs } \\
\text { and symptoms. The aim of this report to present Fahr's syndrome as an } \\
\text { alternative diagnosis of neuropsychiatry symptoms in systemic lupus } \\
\text { erythematosus (SLE) patients. We present a } 17 \text {-year-old teenage girl who } \\
\text { have had a preexisting diagnosis of SLE and have been on remission. The } \\
\text { patient recently had experienced headache, auditory hallucination and } \\
\text { memory loss despite having a low activity score of SLE and no laboratory } \\
\text { relapse. Head CT scan showed bilateral basal ganglia calcifications } \\
\text { suggesting a Fahr's disease. Clinical outcome in this condition might vary } \\
\text { but might worsen neurocognitive functions. }\end{array}$} \\
\hline & \\
\hline & \\
\hline $\mathrm{OI}: 1$ & \\
\hline Onme: Decemoe & \\
\hline \multirow{2}{*}{$\begin{array}{l}\text { Copyright @2020 Authors. } \\
\text { This is an open access article } \\
\text { distributed under the terms } \\
\text { of the Creative Commons At- } \\
\text { tribution-NonCommercial } 4.0 \\
\text { International Licence (http:// } \\
\text { creativecommons.org/licences/ } \\
\text { by-nc/4.0/). }\end{array}$} & \\
\hline & $\begin{array}{l}\text { Sindrom Fahr adalah kondisi yang ditandai dengan kalsifikasi intrakranial } \\
\text { terutama ganglia basalis dan nukleus dentata. Sindrom Fahr adalah penyakit } \\
\text { yang jarang ditemui dengan manifestasi beragam mulai dari asimtomatik } \\
\text { hingga tanda dan gejala neuropsikiatri yang berat. Laporan kasus ini } \\
\text { bertujuan untuk menyajikan penyakit Fahr sebagai salah satu kemungkinan } \\
\text { penyebab gejala neuropsikiatri pada kasus lupus eritematosus sistemik(LES). }\end{array}$ \\
\hline \multicolumn{2}{|r|}{$\begin{array}{l}\text { merupakan seorang remaja perempuan berusia } 17 \text { tahun dengan diagnosis } \\
\text { isi. Pasien mengalami gejala baru berupa sakit kepala, halusinasi auditorik, } \\
\text { un skor aktivitas penyakit dan temuan laboratorium dalam batas normal. } \\
\text { yakit Fahr berdasarkan gejala neuropsikiatri dan adanya kalsifikasi ganglia } \\
\text { uaran klinis penyakit Fahr sangat beragam tetapi dapat mengganggu fungsi } \\
\text { ian hari. }\end{array}$} \\
\hline
\end{tabular}

\section{INTRODUCTION}

Fahr's disease or Fahr's syndrome is a rare condition characterized by abnormal symmetric and bilateral intracranial calcification in some brain regions, especially basal ganglia and dentate nuclei. ${ }^{1,2}$ The general prevalence is less than $1: 1$ 000000 and is uncommon in systemic lupus erythematosus (SLE) patients. ${ }^{3}$ This condition is often asymptomatic and usually discovered in brain imaging, but this can impact a patient's cognitive functions. ${ }^{4}$

Here, we present a SLE patient with brain calcifications in basal ganglia,indicating a Fahr's syndrome. An informed consent has been 
signed by the patient and her parents for this publication.

\section{Case description}

The patient is a 17-year-old teenage girl with systemic lupus erythematosus (SLE). Since five years ago, she has been diagnosed to have SLE based on the American College of Rheumatology (ACR) 1997 and Systemic Lupus International Collaborating Clinics (SLICC) 2012 criteria. Initial manifestations were prolonged fever, malar rash, proteinuria and positive anti-dsDNA and ANA. The patient was treated using SLE protocol with glucocorticoid, which showed a good clinical response with complete remission.

The patient has had an intermittent headache since eight months ago. The headache was felt throughout all head areas, without previous aura and without knowing any precipitating or relieving factors. Also, there was no seizure, loss of consciousness, vomiting or blurry vision. Complete blood count, complement 3 (C3) level and anti dsDNA were in normal limits. However, based on the SLE disease activity index (SLEDAI) scoring evaluation and nervous system involvement, the patient was included in flare and started SLE protocol treatment.

Recently, the patient has experienced new symptoms such as auditory hallucinations, memory loss and mood disorder. Her physical appearances, including blood pressure and neurological examination, are unremarkable. Laboratory investigations for her metabolic profile, renal function and immunological profile were in normal ranges and did not show any flares related to her SLE condition. An electroencephalogram finding indicated an average result. However, the head CT scan a revealed prominent calcification on basal ganglia and cerebral hemisphere, indicating a Fahr's syndrome. To determine secondary causes, the researchers examined calcium serum and parathyroid hormone levels, but none showed remarkable findings.

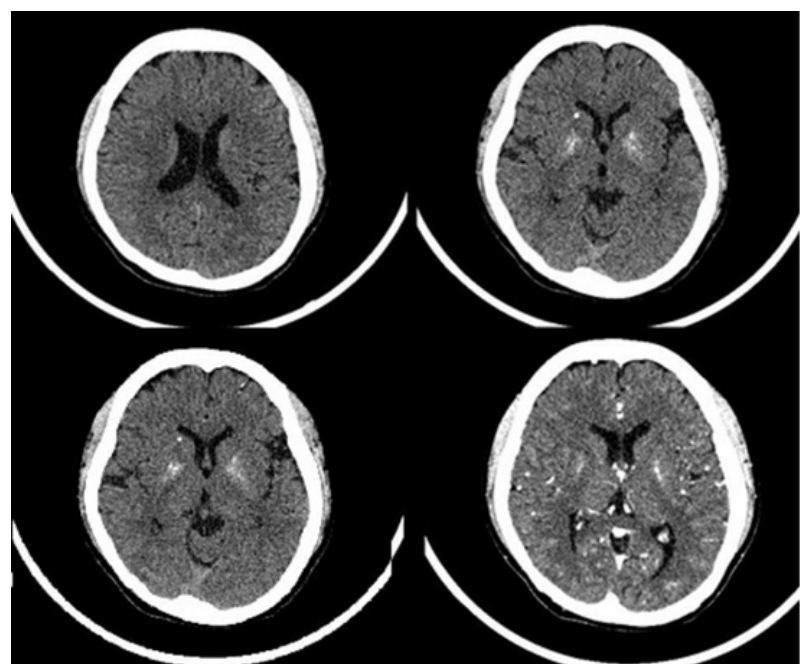

Figure 1. CT scan showed calcifications in certain areas of the brain. Bilateral calcifications in basal ganglia (arrow signs) indicates a Fahr's disease

The patient is currently continuing her SLE protocol with azathioprine $(2 \mathrm{mg} / \mathrm{kg} /$ day) and methylprednisolone $(0.5 \mathrm{mg} / \mathrm{kg} /$ day orally).Ibuprofen and quetiapine were given for psychiatric symptoms. Headache episodes and auditory hallucinations were diminished but, memory loss was somehow persisting. A psychological intervention was also treated for the patient as a supportive treatment. Regular clinical monitoring and neurocognitive assessment were still continued to observe the Fahr's disease condition and outcome. 


\section{DISCUSSION}

Brain calcifications are uncommon findings in systemic lupus erythematosus. ${ }^{5}$ Based on its aetiology, basal ganglia calcifications are classified into primary forms or Fahr's disease, and secondary forms are also known as Fahr's syndrome. ${ }^{2}$ Fahr's disease should be differentiated from Fahr's syndrome of which basal ganglia calcification is secondary to other known genetic, infectious, and metabolic condition disorders such as hypoparathyroidism, disimmunopathies, cytomegalovirus infection, HIV infection, calcified infarct and others. ${ }^{6,7,8}$

Fahr's disease is most commonly transmitted as an autosomal dominant trait, but it may also be passed on as an autosomal recessive or may occur sporadically. ${ }^{1}$ Fahr's disease often affects a person in the fourth to fifth decade of life, although it may occur for a person in childhood. Genetic analyses of large families can affect identified two loci, namely idiopathic basal ganglia calcification (IBGC) 1 located in chromosome $14 \mathrm{q} 48$ and IBGC 2 in chromosome $2 q 37 .^{2}$ The pedigree analysis of this patient showed no other family member who had any neuropsychiatric manifestations.

Disimunnopathies such as SLE have been reported to be associated with brain calcifications. Diffuse calcifications are usually found in the basal ganglia, centrum semiovale, cerebellum and cerebral cortex. ${ }^{2,4}$ Possible mechanism of Fahr's syndrome in SLE is due to primary recurrent immunological vascular damage which triggers microinfarctions with posterior dystrophic calcification. Basal ganglia are the most frequent localization because of the high concentration of calcium in this site. ${ }^{9}$ Fahr's syndrome is characterized by clinical heterogeneity. It could be asymptomatic or associated with neuropsychiatric manifestations. ${ }^{10}$ In Fahr's syndrome, there is no relationship between the degree of calcifications and the neurological presentation. ${ }^{11}$ They are usually seen with motor deficits, but $40 \%$ shows primarily cognitive and other psychiatric findings such as found in this case. Neurological manifestations include movement disorder, syncope, cerebellar ataxia and dementia; meanwhile, psychiatric symptoms include paranoid ideation, delusions, lack of interest, low mood and auditory or visual hallucinations. In this patient, neurological manifestations such as headache, memory loss and psychiatric symptoms with low mood and hallucinations occurred. ${ }^{12}$

Fahr's syndrome should be diagnosed based on clinical aspects, neuroimaging and exclusion of other causes. CT scan and magnetic resonance imaging (MRI) are widely used in clinical practice to identify and quantify mineral deposition. The CT is a preferable method of localizing and assessing the extent of cerebral calcifications. Calcified areas can be easily identified as hyperdense lesions on CT that is considered decisive for an accurate diagnosis. On MRI, calcified areas show a lowintensity signal on a T2 image and low or highintensity signals on a T1 weighted plane. ${ }^{1,2}$ Fahr's disease or syndrome can be detected if symmetrical calcifications are found in basal ganglia, cerebellum, thalamus and subcortical white matter as the researchers found in this patient (see figure 1)..$^{13,14}$

Specific haematologicaland biochemical investigations should be conducted to differentiate between Fahr's disease and syndrome. Suggested examination panel consisting of serum concentrations of calcium, phosphorus, magnesium and parathyroid hormone, was completed in this case, and it showed a normal result. Based on the clinical findings and supportive examinations, the researchers tended to correlate Fahr's syndrome caused by this basal ganglia calcification due to disimmunopathies of SLE. However, in cases that no other primary cause for brain calcification is detected or if family history indicates autosomal inheritance, molecular genetic testing should be conducted to diagnose a primary form of basal ganglia calcification or Fahr' disease. ${ }^{1}$

To this date, various treatments have been 
administered to Fahr's patients to achieve remission ar at least stabilization. ${ }^{1} \mathrm{~A}$ treatment for Fahr's syndrome is directed to its specific aetiology, especially if derangement is concise such as correction of phosphate and calcium level in parathyroid disorder. ${ }^{1,15}$ However, in other aetiologies, the treatment is mainly symptomatic. A pharmacological treatment should be conducted to improve anxiety anddepression and to alleviate dystonia. A use of antipsychotic may be used in those presenting with psychotic symptoms. ${ }^{16}$ Use of haloperidol or lithium carbonate has been reported to help patients with psychotic symptoms, but none has been studied in pediatric population. In this case, quetiapine was given as antipsychotic and showed improvement in auditory hallucinations. ${ }^{7,17}$

Prognosis is various and unpredictable. Since the clinical outcome is unrelated to the extent of calcification, the prognosis is difficult to predict. ${ }^{18}$ Serial CT scan performed in patients with Fahr's disease showed a progressive increase in calcification and cerebral atrophy consequences. The calcification may turn into serious condition as the patients grow older, and symptoms may also become worse to make a disability and debilitating symptoms. ${ }^{16,17}$

\section{CONCLUSION}

Fahr's syndrome is a secondary form of basal ganglia calcification with various clinical presentations. Its clinical findings are broad from asymptomatic condition to severe neuropsychiatry signs and symptoms. Fahr's syndrome should be considered an alternative to diagnosis in patients with SLE despite having a low level of disease activity but showing a new onset of neurological or psychiatric clinical manifestations.

\section{CONFLICT OF INTEREST}

There was no conflict of interest.

\section{ACKNOWLEDGEMENT}

The researchers would thank to the patient and her parents for making this report published.

\section{REFERENCES}

1. Saleem S, Aslam HM, Anwar M, Anwar S, Saleem M, Saleem A, et al. Fahr's syndrome: Literature review of current evidence. Orphanet J Rare Dis. 2013;8:1.

2. Donzuso G, Mostile G, Nicoletti A, Zappia M. Basal ganglia calcifications (Fahr's syndrome): related conditions and clinical features. J Neurol Sci. 2019;40:2251-63.

3. Gligorievski A. CT Diagnosis of Fahr disease , a case report. Clin Case Rep Rev. 2018;4:13.

4. Gülsün M, Baykiz AF, Kabataş S, Belli H. Fahr syndrome: Three cases presenting with psychiatric signs. Eur J Gen Med. 2006;3:35-40.

5. Martinovic-Kaliterna D, Radic M, Radic J, Kovacic V, Fabijanic D. Massive cerebral calcifications (Fahr's disease) in a patient with systemic lupus erythematosus and no major neuropsychological abnormality. Isr Med Assoc J. 2013;15:654-5.

6. Lippmann S, Perugula ML. Differential Diagnoses: Fahr's Disease or Fahr's Syndrome. Innov Clin Neurosci. 2018;13:45-8.

7. Kundu GK, Bhadra S, Ahmed S. BAOJ Pediatrics A Child with Fahr's Disease. BAOJ Pediat. 2017;

8. Otu AA, Anikwe JC, Cocker D. Fahr's disease: a rare neurological presentation in a tropical setting. Clin Case Reports. 2015;3:8068.

9. Cañas CA, Tobón GJ. Multiple brain calcifications in a patient with systemic lupus erythematosus. Clin Rheumatol. 2008;27:635.

10. Cavalcanti-Mendes GDA, De Carvalho GTC, Christo PP, Malloy-Diniz LF, De Sousa AA. An unusual case of Fahr's disease. Arq Neuropsiquiatr. 2009;67:516-8.

11. Filloux V, Marotte H, Miossec P. Cerebral calcifications in an elderly lupus patient [11]. Vol. 62, Annals of the Rheumatic Diseases. 2003. p. 283-4.

12. Sinha R, SIngh D, John BM. Fahr's Disease: A Case Report. J Nepal Paediatr Soc. 
2009;30:44-5.

13. Sahin N, Solak A, Genc B, Kulu U. Fahr disease: use of susceptibility-weighted imaging for diagnostic dilemma with magnetic resonance imaging. Quant Imaging Med Surg. 2015;5:628-32.

14. Govindarajan A. Imaging in Fahr's disease: How CT and MRI differ? BMJ Case Rep. 2013;1-2.

15. Naqvi S, Arshad S, Hanif R, Elfert KAH. Fahr's Syndrome Misdiagnosed as Schizophrenia: A Case Report. Cureus. 2017;9:25.

16. Lam JSP, Fong SYY, Yiu GC, Wing YK. Fahr's disease: A differential diagnosis of frontal lobe syndrome. Hong Kong Med J. 2007;13:75-7.

17. Wang H, Shao B, Wang L, Ye Q. Fahr's disease in two siblings in a family a case report. Exp Ther Med. 2015;9:1931-3.

18. CalabrÒ RS, Spadaro L, Marra A, Bramanti P. Fahr's disease presenting with dementia at onset: A case report and literature review. Behav Neurol. 2014;2014. 